\title{
On the cultivation mode of Applied University Teachers
}

\author{
Xie $\mathrm{Jie}^{1, \mathrm{a}}$ \\ ${ }^{1}$ Jiangxi Science \& Technology Normal University, Nanchang, Jiangxi, 330013, P.R. China \\ a503790861@qq.com
}

Keywords: Application, College education, Teacher training

\begin{abstract}
In today's society, the rapid development of higher education, and has been popular for the public. According to the demand of social economic development, it is urgent to cultivate a large number of high quality applied talents in university education. In this paper, we discuss the teacher training model of the application oriented universities.
\end{abstract}

\section{Introduction}

With the rapid development of economy and technology, the university education is also in the process of exploration and development. With the popularization and development of education, the higher education is developing rapidly, especially the ordinary universities and colleges. From the beginning of the general position, the direction of the chaos is gradually developing. For example, some ordinary local universities from the beginning to establish a comprehensive, academic, famous at home and abroad to gradually shift to the establishment of a variety of, applied colleges, to achieve a combination of economic and social development.

Application oriented university education is an important part of higher education, and it is also an indispensable source of Applied Talents in social and economic development, especially for local economic and social development, has been playing a very important role. Among the many conditions of cultivating excellent applied talents, how to cultivate the excellent teachers is a key factor in the development of excellent teachers.

\section{Basic requirements of application oriented university teachers}

Because of the importance of application oriented universities in society and the important role of Applied Talents in society, the special and important basic requirements for teachers are also very important. First, the main responsibility of the application oriented university teaching and education, the teachers must have a solid professional knowledge, solid scientific research and education teaching ability, must have a good professional ethics, social morality. At present, the application of the University's quality and moral aspects of students, learning enthusiasm is relatively poor, the foundation is relatively short, the need for teachers to pay more patience, love and establish a correct positive image. Second, for the application oriented universities in the cultivation of applied talents, the teachers must have a good knowledge of the industry and good practical knowledge and ability, can be a good solution to a series of problems in the process of professional practice.

\section{Current situation and problems of application oriented university teachers}

Now the society is diversified, the application oriented personnel training objectives are also diversified, so the selection of teachers, training and evaluation, etc., will be because of the positioning of the University and the development strategy of different trends and diversification. The source of teachers is relatively simple, it is difficult to meet the needs of the conditions required.

The research on the status quo of application oriented university teachers has a long history, and it has the following several aspects:

The application of the structure of the University Teachers. At present, the proportion of teachers and students in the applied university, the proportion of the structure of the title structure, 
and the high degree of teachers in the teaching staff (master and teachers) accounted for most of the country is below the general level, with foreign teachers is a far cry. Sports application type undergraduate division general in 1271, art application type undergraduate division general 9.63 and other application type undergraduate general between 14.5-17.5. In terms of the structure of the title, the private colleges and universities have obvious advantages.

Practical teaching staff in the application oriented Universities. According to the relevant survey data, in our country, the practical teaching of the teachers is relatively reasonable. But compared with the overseas, this area is still relatively lacking, for example Hannover University of applied sciences require training teacher has at least 5 years of experience in professional practice, in addition to must have a solid education teaching theory, we in the practice teaching, and also lack a lot, teachers also need to further enhance.

\section{Discussion on Teacher Training Model}

Optimize the structure of Teachers. Need a large number of senior applied talents of . 1) the process of social development, but in the traditional concept of "heavy and light", on the application of University and talent there was a bias, which makes many difficulties appear in the personnel training and the process of the introduction of teachers. Therefore, the first step is to change the structure of the academic elite for the purpose of the concept, pay attention to the cultivation of high quality applied talents, especially in the application oriented university teachers, to their own personal action to education and practice, and actively establish a positive image, to gradually influence and slowly change public opinion.

2) the need to increase the intensity of the introduction of more channels of teachers. First, teachers are mostly the school yuan graduates stayed or recruited from other colleges and universities fresh yuan graduates, a single source. The basic professional knowledge, which has a good scientific research teaching ability, but because the practice experience is too little, or has never been in the job, leading to the industry's cognition is relatively backward and closed. Therefore, the university should be appropriate to introduce a number of experienced teachers with high qualifications, to guide the new teacher just entering or not. Secondly, we should strengthen the school enterprise cooperation, the teachers in the enterprise to carry out the practice of the experience, and hire a company to have a wealth of practical experience in the school to do a lecture or a part-time teacher, so that the school's teachers and front-line professionals to conduct in-depth exchanges and explore, to make up for the school teachers in the industry's cognitive gap. Secondly, it should be appropriate to introduce a number of professional master, doctoral and senior professional title of teachers, so as to improve the proportion of teachers and students, and the problem of high professional titles and other issues, to solve the problem of teacher stress, the authority is not enough and so on.

Training "double teacher" teacher. In the academic circles, there are many arguments about the connotation of "double qualified teachers", whether it is "double title" or "dual energy (quality)" theory, or "double level" theory, the main idea is to improve the teaching ability of teachers, technology and scientific research ability. However, let each person to achieve the all-round is not realistic, so I personally understand, "double" teachers refers to a group of teachers, a comprehensive to achieve all-round collective.

1) foreign "double qualification" teacher training, taking Austria University of science and technology as an example

Austria University of science and technology can be divided into ordinary university teachers can be divided into three categories of ordinary, professional and practical training. The ordinary teachers carry out some basic cultural courses, such as German, mathematics, etc.. The practical operation of the students in the position of the practical training. And, $85 \%$ of these teachers in the master's degree and above, only a doctoral degree, more than 30\%. Austrian vocational teachers into the pre job generally six to nine semester training, then take an exam to obtain the corresponding degree, in the training process need to learn to solve various later problems that may arise in the teaching ability and solid teaching ability etc.. The legal provisions of the professional teachers in Austria every year to 
participate in various seminars and training, etc., in order to maintain a constant awareness of the industry and technology. With strict entry and continuing education and training system should be relatively, Austria University of science and technology also has a strict and reasonable treatment system, can adjust wages and subsidies, etc..

2) the study on the training mode of "double qualified teachers" in China

Foreign application oriented university teachers are the basic requirements of the corresponding professional master as well as on the degree, not less than 18 months of internship, which has a title, it is a need for at least 5 years of business experience, and foreign application oriented university teachers in the resources of $60 \%$ of the total. Referring to the introduction and training mode of "double qualified teachers" in foreign countries, the basic situation and problems encountered in the process of application oriented university teacher training can be solved. The following ways can be used to solve the problems, and to cultivate excellent applied university teachers.

In the domestic exploration of the application oriented university teachers in the process of training, there are some successful methods can be used for reference, such as Huangshan University, the new and old teachers to carry out professional quality research and training, the establishment of a teaching salon, to carry out the main activities of the famous teacher, improve the ability and quality of teachers, and also made some of the more remarkable results. Some of the other applications of the University also use a variety of platform to train the application type of young teachers, or the combination of enterprises or school enterprise combination as the goal, these methods have a distinct regional characteristics, with some open features, but also to achieve some results.

\section{Conclusion}

In the application oriented university, the outstanding teachers are the important conditions for the application of the training of applied talents, we should first locate the school's own development goals, and then integrate their own teaching position, development strategy and regional characteristics and other conditions, according to local conditions to develop their own practical needs of teachers training model.

This paper is one of the research results of "application oriented university teacher training model".(NO. GJ1217)

\section{References}

[1] W. Zhang. The current mode of teacher training in Colleges and universities to explore the. era of education, 2013 (09)

[2] G.S. Li. On how to make good use of the teaching staff of the university to develop the work of. course education research, 2012 (11) 